\title{
Research
}

\section{In vitro evaluation of the effect of soft drinks on dental erosion}

\author{
Nádia Lopes, Maria de Lurdes Pereira, Helena Salgado*, Américo Afonso, Pedro Mesquita
} Faculdade de Medicina Dentária (FMDUP), Porto, Portugal

\section{A R T I C L E I N F O}

\section{Article history:}

Received 31 March 2017

Accepted 30 September 2017

Available online 25 October 2017

\section{Keywords:}

Beverage

Dental enamel

Tooth demineralization

Tooth erosion

\begin{abstract}
A B S T R A C T
Objective: The relationship between the exposure to Coca-Cola ${ }^{\circledR}, \mathrm{Fanta}^{\circledR}$ Orange and Lipton ${ }^{\circledR}$ Ice Tea ${ }^{\circledR}$ Lemon and dental erosion over time was assessed, as well as the possible existence of differences in their erosive potential.

Methods: Ninety-six samples were randomly assigned in equal numbers to four groups: Coca-Cola ${ }^{\circledR}$, Fanta ${ }^{\circledR}$ Orange, Lipton ${ }^{\circledR}$ Ice Tea Lemon and a control group. Cycles of demineralization/remineralization were performed under stirring for 5 minutes, 3 times daily, for 30 days. Cuts of approximately 100-150 $\mu \mathrm{m}$ in thickness were made in the display window with a hard tissue microtome and the samples were analyzed under a light microscope. The depth of demineralization was measured. Data were analyzed using the Kruskal-Wallis and U-Mann-Whitney tests. A significance level of 0.05 was used.

Results: All groups, except for the control, promoted wear on tooth surfaces. Coca-Cola ${ }^{\circledR}$, over time, caused the greatest loss of tooth structure. The differences between the three drinks at day 30 were not statistically significant $(p>0.05)$.

Conclusion: The consumption of the three drinks, over time, caused loss of tooth structure, incrementally. There were no differences in the erosive potential of the soft drinks studied after a 30-day exposure period. (Rev Port Estomatol Med Dent Cir Maxilofac. 2017;58(3):139-145)
\end{abstract}

(C) 2017 Sociedade Portuguesa de Estomatologia e Medicina Dentária. Publicado por SPEMD. Este é um artigo Open Access sob uma licença CC BY-NC-ND (http://creativecommons.org/licenses/by-nc-nd/4.0/).

\footnotetext{
${ }^{*}$ Corresponding author.

Correio eletrónico: helenatsalgado@gmail.com (Helena Salgado).

http://doi.org/10.24873/j.rpemd.2017.10.024

1646-2890/@ 2017 Sociedade Portuguesa de Estomatologia e Medicina Dentária. Published by SPEMD.

This is an open access article under the CC BY-NC-ND license (http://creativecommons.org/licenses/by-nc-nd/4.0/).
} 


\section{Avaliação in vitro do efeito de refrigerantes na erosão dentária}

\section{R E S U M O}

\section{Palauras-chave:}

Refrigerantes

Esmalte dentário

Desmineralização dentária

Erosão dentária
Objetivo: Avaliação da relação da exposição à Coca-Cola ${ }^{\circledR}$, Fanta ${ }^{\circledR}$ Laranja e Lipton ${ }^{\circledR}$ Ice Tea ${ }^{\circledR}$ Limão ao longo do tempo e a erosão dentária bem como a possível existência de diferenças no potencial erosivo entre as bebidas.

Métodos: Noventa e seis amostras foram aleatoriamente distribuídas, em igual número, por 4 grupos: Coca-Cola ${ }^{\circledR}$, Fanta ${ }^{\circledR}$ Laranja, Lipton ${ }^{\circledR}$ Ice Tea Limão e grupo controlo. Ciclos de desmineralização/remineralização foram realizados, durante 5 minutos, 3 vezes ao dia, durante 30 dias. Realizaram-se cortes, na janela de exposição, de aproximadamente 100-150 $\mu \mathrm{m}$ de espessura com um micrótomo de tecidos duros. As amostras foram analisadas ao microscópio de luz polarizada, e realizou-se a medição da profundidade de desmineralização. Os dados foram analisados pelos testes Kruskal-Wallis e U-Mann-Whitney. O valor da significância estatística utilizada foi 0,05.

Resultados: Todos os grupos, exceto o grupo controlo, promoveram erosão dentária. A Coca-Cola ${ }^{\circledR}$, ao longo do tempo, promoveu a maior perda de estrutura dentária. As diferenças entre as três bebidas, aos 30 dias, não se revelaram significativas $(p>0,05)$.

Conclusão: O consumo destes três refrigerantes, ao longo do tempo, promoveu perda de estrutura dentária de forma crescente. Não se verificaram diferenças no potencial erosivo dos refrigerantes estudados aos 30 dias de exposição. (Rev Port Estomatol Med Dent Cir Maxilofac. 2017;58(3):139-145)

(c) 2017 Sociedade Portuguesa de Estomatologia e Medicina Dentária. Publicado por SPEMD. Este é um artigo Open Access sob uma licença CC BY-NC-ND (http://creativecommons.org/licenses/by-nc-nd/4.0/).

\section{Introduction}

In the past years, there has been a great increase in the incidence of dental erosion. This phenomenon has become of great interest for clinicians and researchers, especially regarding its causal factors. ${ }^{1-4}$

The dental erosion is a slow and chronic pathological process, in which there is an irreversible loss of dental hard tissue as a result of a chemical attack without involving bacteria; it always involves acids. Being a continuous process over time, it often leads to extensive exposure of the dentin, resulting in teeth with unsightly appearance, hypersensitivity and a consequent reduction of the masticatory function. ${ }^{1,3,5-13}$

The causes of dental erosion may be intrinsic, as in the case of pathologies that cause gastric juice regurgitation, or extrinsic, when they are associated with the diet (acidic beverages and fruit), the environment (chemicals, chlorine from pools) or drugs (vitamin C, aspirin). Despite the variety of causal factors, it has been found that the acids present in the diet and the intrinsic stomach acids are the most important factors in this process. $1,8,10,14$

Erosion is clinically relevant when an unfavorable variety of factors influences the tooth surface. ${ }^{15}$ The erosion is a cumulative multifactorial condition. The interplay of chemical, biological and behavioral factors is fundamental to the understanding of its etiology. ${ }^{16-18}$

The biological factors involved in this process include saliva, acquired pellicle, tooth structure, and teeth position in relation to soft tissues and the tongue. The behavioral factors associated with dental erosion, like eating and drinking habits, regular exercise with dehydration and decrease of salivary flow, excessive oral hygiene and, moreover, an unhealthy lifestyle such as chronic alcoholism, are predisposing factors for this process. ${ }^{16}$

The erosive potential of different agents, such as soft drinks, depends on a variety of chemical factors, e.g. low $\mathrm{pH}$, titratable acidity, mineral content, composition of the drink (acid), clearance on tooth surface and its calcium-chelation properties. ${ }^{6,8,9,11,16,17,19-21}$

There is some evidence that the dental erosion is strongly associated with the frequency and amount of soft drinks intake. Moreover, its consumption has increased, causing worldwide concern because of the risk of dental erosion. 1,4,6,14,16,19,20

Those beverages are constituted by various types of acids that contribute to their low $\mathrm{pH}^{6,22}$ Another factor that can influence the potential erosion caused by soft drinks is the saliva since, after ingestion, a residual amount of liquid remains in the oral cavity contacting with the teeth. Various salivary protective mechanisms come into play during an erosive challenge, such as dilution, clearance, neutralization, buffering the acid, and slowing down the rate of enamel dissolution through the common ion effect caused by salivary calcium and phosphate. 3,16

The aim of this study was to measure the relationship between the exposure to some soft drinks, including Coca-Cola ${ }^{\circledR}$, Lipton ${ }^{\circledR}$ Ice Tea Lemon and Fanta ${ }^{\circledR}$ Orange, and dental erosion. The hypothesis considered was that the drinks studied cannot promote dental erosion. 


\section{Material and Methods}

This study was approved by the Ethics Committee of the Faculty of Dental Medicine of the University of Porto.

Forty-eight intact human teeth (premolars and molars), extracted for orthodontic and periodontal reasons, were cleaned of residual debris, disinfected and stored in distilled water. All the teeth were analyzed under the microscope. Teeth presenting deformities (fluorosis, enamel hypoplasia, tooth decay) were excluded from the study. All the teeth were fixed with resin (Epofix $^{\circledR}$, Struers, Denmark) and sectioned mesiodistally with a hard tissues microtome (Acuttom ${ }^{\circledR}$, Struers, Denmark), resulting in ninety-six samples. Each sample was covered with an acid-resistant varnish (Risqué ${ }^{\circledR}$ nail polish color cappuccino Niasi Arabica, Brazil), except for a 4-mm-diameter window.

The $\mathrm{pH}$ of the beverages used for the immersion cycles was measured with a digital pH meter (pH GLP MultiCal $540^{\circledR}$, WTW, Sigma Aldrich, Portugal). The electrode was previously calibrated at the start of each session using standard solutions. The $\mathrm{pH}$ was measured at three different consecutive times: immediately after opening, 5 minutes after and 30 minutes after. 2,6,10

Four experimental groups were analyzed: Coca-Cola ${ }^{\circledR}$, Lipton ${ }^{\circledR}$ Ice Tea Lemon, Fanta ${ }^{\circledR}$ Orange and a control group (preserved in a sodium chloride physiological solution). The samples were randomly assigned in equal numbers $(n=8)$ to the groups.

All the experimental groups were subjected to cycles of demineralization/remineralization. The samples were immersed for 5 minutes in $75 \mathrm{ml}$ of the beverage selected, under mild stirring by a magnetic stirrer (Jenway $1000^{\circledR}$, Keison, UK). This procedure was repeated for each sample, three times a day with a four-hour interval between the immersion cycles. After each immersion cycle, the samples were washed with distilled water, dried with gauze and maintained in an incubator in physiological sodium chloride at $37^{\circ} \mathrm{C}$ (HERAEUS ELECTRONIC $^{\circledR}$, Gaprüfte Sicherheit, German) until the following immersion cycle. The control samples were immersed in a sodium chloride physiological solution $(\mathrm{pH} 6.5)$ at $37^{\circ} \mathrm{C}$ with daily change of the solution. ${ }^{1}$

The cycling regimen was repeated for a total of 30 days. After seven days, eight samples from each experimental group were removed randomly, washed in distilled water and stored in a moist environment until analysis. This process was repeated on days 15 and 30.1,24

The samples were sectioned through the middle of the exposure window, using a hard tissue microtome (Acuttom ${ }^{\circledR}$, Struers, Denmark). They were then polished with a manual polisher (Struers ${ }^{\circledR}$, Denmark), thus resulting in sections of approximately $100-150 \mu m$ thickness. The sections were immersed in distilled water and analyzed using a polarizing light microscope (Leica ${ }^{\circledR}$ DMLB, Wetzlar, Germany), at a 50-times magnification. ${ }^{2,8}$

The produced demineralization lesions were analyzed by a single examiner. Based on a line formed by the crossed wires in the scale, connecting the remaining unaffected surface enamel adjacent to the lesion, three depths of demineralization were recorded in each section, with the help of a Leica Microsystems (Schweiz ${ }^{\circledR}$, Leica Microsystems, Wetzlar, Germany) AG software $\left(\right.$ Leica $^{\circledR}$ System Application Suit - LAS Core version 3.5.0, Wetzlar, Germany). The demineralization results were tabulated..$^{2,8}$

All statistical procedures were performed using statistical software (IBM ${ }^{\circledR}$ program computer SPSS 19). The quantitative results were presented as mean \pm standard deviation. The nonparametric tests Kruskal-Wallis and Mann-Whitney-U with Bonferroni correction were used for comparing groups. A significance level of 0.05 was used.

\section{Results}

The $\mathrm{pH}$ values of the three drinks, represented as means and standard deviations, are shown in Table 1. The composition of each soda product, according to manufacturers, is shown in Table 2.

The results obtained from the demineralization/remineralization cycles are shown in Figure 1.

Regarding noting wear promoted by each drink over time, Coca-Cola ${ }^{\circledR}$ showed the highest percentage of erosion on day $7(61.4 \%)$, and this value lowered to $31.5 \%$ on day 15 , and to $7.07 \%$ on day 30 . These differences are statistically significant $(p<0.05)$. Regarding the different experimental times for Coca-Cola ${ }^{\circledR}$ (Figure 2), there were no statistically significant differences $(p>0.05)$ between day 15 and day 30 .

The Fanta ${ }^{\circledR}$ Orange group showed the same trend, i.e., a higher percentage of demineralization on day 7 (59.7\%) than

Table 1. Mean pH values ( \pm standard deviation) for each beverage, over time.

\begin{tabular}{cccc} 
Time & \multicolumn{3}{c}{ Mean \pm SD } \\
\cline { 2 - 4 } (minutes) & Coca-Cola $^{\circledR}$ & $\begin{array}{c}\text { Fanta }^{\circledR} \\
\text { Orange }\end{array}$ & $\begin{array}{c}\text { Lipton } \\
{ }^{\circledR} \text { Ice Tea } \\
\text { Lemon }\end{array}$ \\
\hline $\mathbf{0}$ & $2.50 \pm 0.047$ & $3.17 \pm 0.019$ & $3.29 \pm 0.020$ \\
\hline $\mathbf{5}$ & $2.50 \pm 0.070$ & $3.15 \pm 0.028$ & $3.29 \pm 0.014$ \\
\hline $\mathbf{3 0}$ & $2.58 \pm 0.008$ & $3.17 \pm 0.009$ & $3.29 \pm 0.013$ \\
\hline
\end{tabular}

Table 2. The selected beverages and ingredients as listed on the beverage bottles.

\begin{tabular}{|c|c|}
\hline Soft drinks & Composition \\
\hline $\begin{array}{l}\text { Coca-Cola }{ }^{\circledR} \\
\text { (The Coca-Cola }^{\circledR} \\
\text { Company. Refrige, S.A., } \\
\text { Cabanas, Portugal) }\end{array}$ & $\begin{array}{l}\text { Water, sugar, carbon dioxide, caramel } \\
\text { color (E-150d), E338 acidifier } \\
\text { (phosphoric acid), natural flavors, } \\
\text { caffeine. }\end{array}$ \\
\hline $\begin{array}{l}\text { Fanta }{ }^{\circledR} \text { Orange } \\
\text { (The Coca-Cola } \\
\text { Company. Refrige, S.A., } \\
\text { Cabanas, Portugal) }\end{array}$ & $\begin{array}{l}\text { Water, sugar and/or glucose-fructose } \\
\text { syrup, } 8 \% \text { of orange juice, carbon } \\
\text { dioxide, acidifier citric acid, flavoring, } \\
\text { potassium sorbate preservative, E- } 414 \text {, } \\
\text { E-412 and E- } 445 \text { stabilizers, } \\
\text { antioxidants: ascorbic acid and beta } \\
\text { carotene dye. }\end{array}$ \\
\hline $\begin{array}{l}\text { Lipton }{ }^{\circledR} \text { Ice Tea Lemon } \\
\text { (Unilever Jerónimo } \\
\text { Martins, Lda, Lisbon, } \\
\text { Portugal) }\end{array}$ & $\begin{array}{l}\text { Tea, water and black tea extract ( } 4.7 \%) \text {, } \\
\text { sugar, acidity regulators: citric acid and } \\
\text { sodium citrate, lemon juice }(0.1 \%) \text {, } \\
\text { antioxidants: ascorbic acid. }\end{array}$ \\
\hline
\end{tabular}




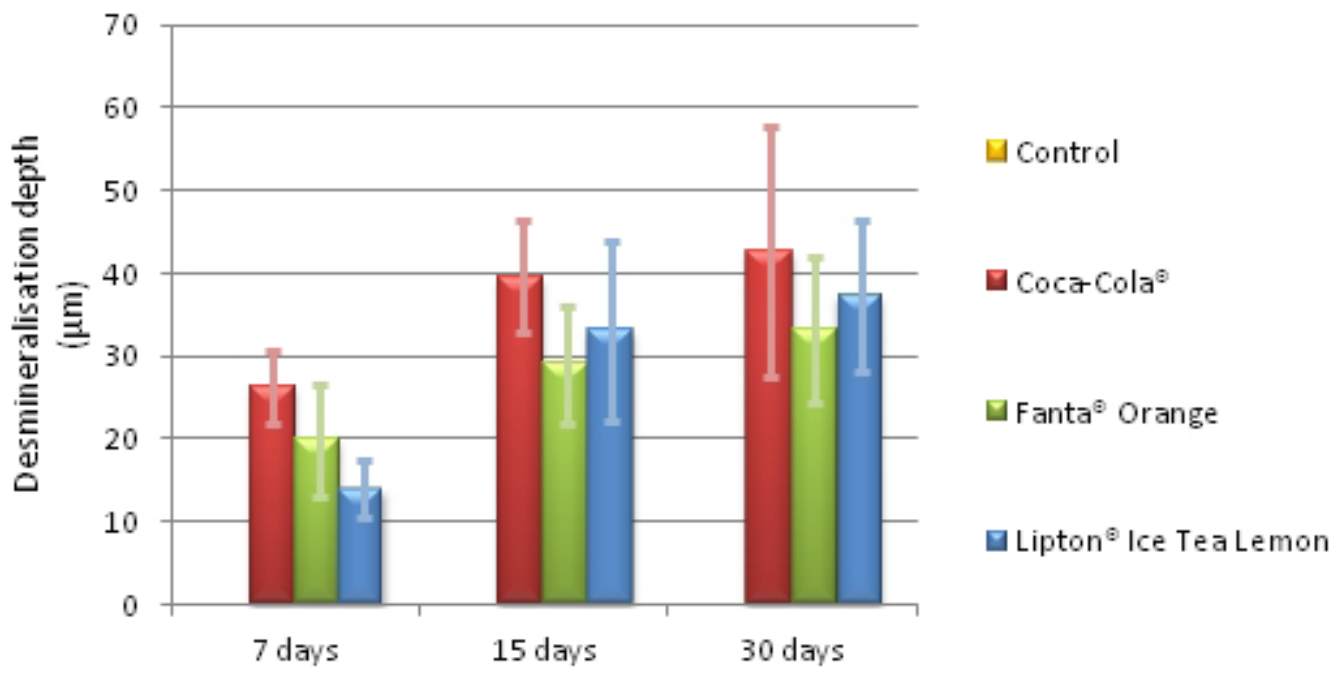

Figure 1. Comparison of the mean and standard deviation of the demineralization depth observed in 4 experimental groups along the time of study.
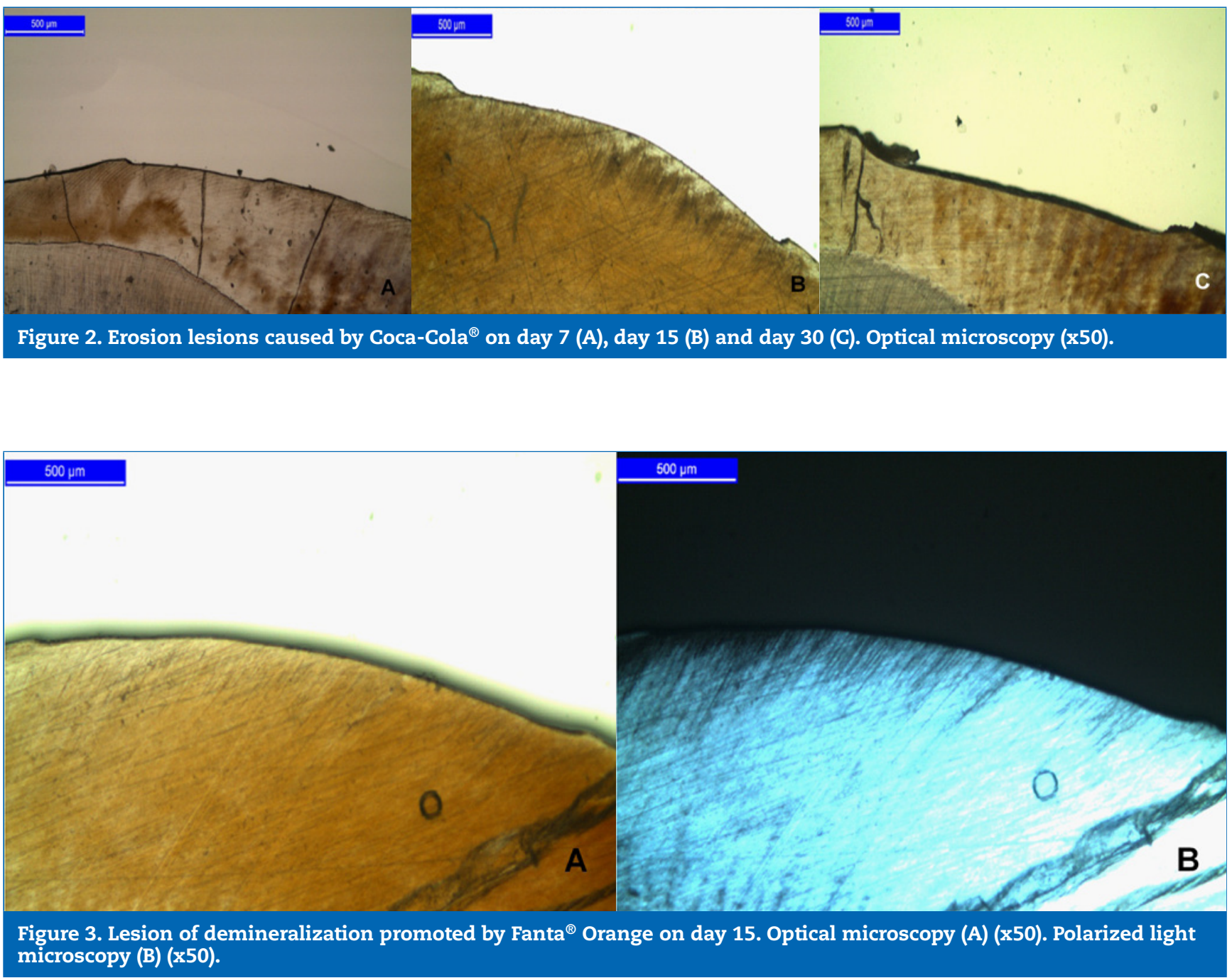


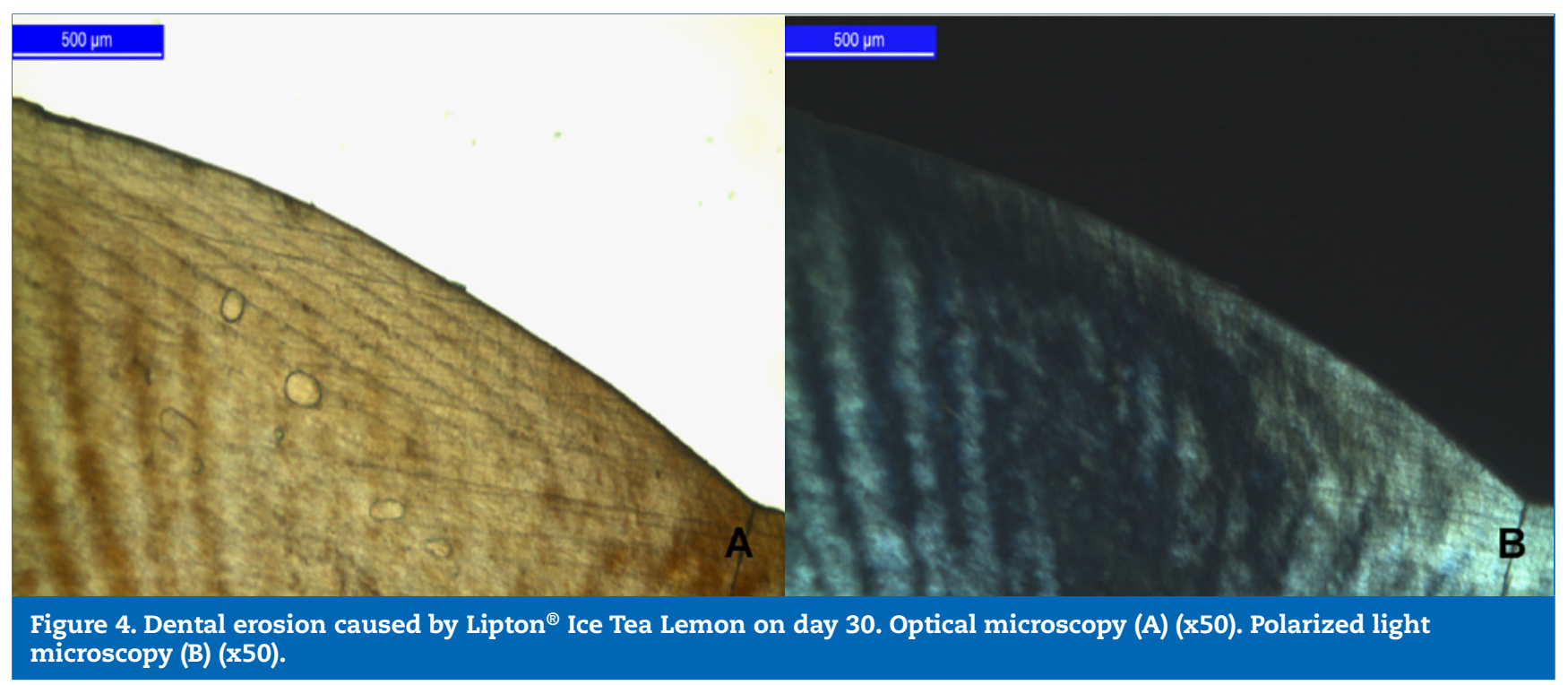

on day $15(27.5 \%)$ and day $30(12.7 \%)$, with these differences being statistically significant $(p<0.05)$ (Figure 3$)$. Regarding the three experimental periods for Fanta ${ }^{\circledR}$ Orange, there were no statistically significant differences between day 7 and day 15 and between day 15 and day 30 ( $p>0.05)$.

For the Lipton ${ }^{\circledR}$ Ice Tea Lemon group, the highest wear percentage occurred on day 15 (51.36\%), followed by day 7 (37.34\%) and day $30(11.3 \%)$, and these differences were statistically significant $(p<0.05)$. Regarding the experimental times, there were no statistically significant differences $(p>0.05)$ between day 15 and day 30 (Figure 4).

The comparison of the wear caused by the three drinks on day 7 showed statistically significant differences $(p<0.05)$. By assessing the wear promoted by drinks on day 7, we found statistically significant differences between the Coca-Cola ${ }^{\circledR}$ group and the Lipton ${ }^{\circledR}$ Ice Tea Lemon group.

On day 15 , Coca-Cola ${ }^{\circledR}$ promoted the greatest wear, followed by Lipton ${ }^{\circledR}$ Ice Tea Lemon and Fanta ${ }^{\circledR}$ Orange. However, the differences observed at this time were not statistically significant ( $p>0.05)$.

When assessing the demineralization depth on day 30 , it was observed that the Coca-Cola ${ }^{\circledR}$ group achieved the highest average wear of all sodas. However, these wear differences were not statistically significant $(p>0.05)$.

\section{Discussion}

The results of the present study suggest that Coca-Cola ${ }^{\circledR}$, Fanta ${ }^{\circledR}$ Orange and Lipton ${ }^{\circledR}$ Ice Tea Lemon have an increasing erosive potential over time.

By analyzing the obtained $\mathrm{pH}$ values over time, we found that Coca-Cola ${ }^{\circledR}$ was the drink with the lowest value. Lipton ${ }^{\circledR}$ Ice Tea Lemon was the beverage with the highest $\mathrm{pH}$ value.

In the group with the lowest $\mathrm{pH}\left(\mathrm{Coca}-\mathrm{Cola}^{\circledR}\right)$, there was a greater loss of the dental structure. However, the Lipton ${ }^{\circledR}$ Ice Tea Lemon group had a higher loss of tooth substance than the Fanta ${ }^{\circledR}$ Orange one, which had a greater $\mathrm{pH}$ (Figure 1). It is not possible to establish a direct association between the beverage $\mathrm{pH}$ and the erosive potential. Similar results were obtained by other authors. ${ }^{6,10,15,25-28}$

Other inherent beverage's factors such as acidity, mineral content, adherence to the tooth surface and chelation of calcium property may help to explain the wear differences promoted by the three drinks. ${ }^{1,10,11,15,25,26}$

The presence of different kinds of acids may also help to explain the differences in the erosive potential established between the three beverages. Coca-Cola ${ }^{\circledR}$ has phosphoric acid in its composition while Fanta ${ }^{\circledR}$ Orange and Lipton ${ }^{\circledR}$ Ice Tea Lemon have citric acid, according to information obtained from the manufacturers. ${ }^{19}$

The literature is contradictory regarding the erosive potential of beverages containing citric acid or phosphoric acid. One ${ }^{(1)}$ study showed that the beverages containing phosphoric acid are more erosive than those containing citric acid while other showed the opposite. ${ }^{19,20}$

The critical $\mathrm{pH}$, beyond which the hydroxyapatite dissolves, is 5.5 and all soft drinks used in this study had $\mathrm{pH}$ values well below this value. The intraoral $\mathrm{pH}$ which is generally 6.8 , decreases to less than 5.2 just 3 minutes after the consumption of the soft drink. ${ }^{21,25,26}$

After drink ingestion, an increase in salivary flow occurs. The bicarbonate levels in saliva are positively correlated to the salivary flow rate, which means that a higher saliva flow leads to a higher $\mathrm{pH}$ and higher buffering capacity. Despite this increase, it takes about 25-30 minutes for the $\mathrm{pH}$ to return to intraoral physiological values. The greater the ability to titrate the beverage, the greater the time necessary for the saliva to neutralize the acid. $1,6,14,21,23,25-27$

In a similar study, 15 the authors evaluated the mineral loss caused by soft drinks, using microanalysis performed by an electronic probe at various depths as an evaluation method. In that study, enamel slabs were immersed for 6 hours in many beverages, namely, Coca-Cola ${ }^{\circledR}$ (pH 2.3) and Lipton ${ }^{\circledR}$ Ice Tea Lemon ( $\mathrm{pH}$ 2.9). As in the present study, those authors found 
that the mineral loss promoted by Lipton ${ }^{\circledR}$ Ice Tea Lemon on the enamel occurred on a smaller scale compared to Coca- Cola ${ }^{\circledR} \cdot{ }^{15}$

Another study ${ }^{10}$ assessed the demineralization depth caused by some acidic drinks, including Coca-Cola ${ }^{\circledR}(\mathrm{pH}$ 2.65), on the enamel surface. In that study, the teeth were immersed in the drinks for 25 consecutive hours. Using the same methodology as in the present study, the enamel immersed in Coca-Cola ${ }^{\circledR}$ showed an average depth loss of $92+/$ -62 micrometers. ${ }^{10}$ This loss was greater than that found in this study. However, the study by Ehlen et al. exposed the teeth to the drinks without taking into account the rate of consumption of the drink, the period of time the beverage is in the mouth prior to swallowing, or the saliva's potential of remineralization; thus, these conditions may have exacerbated the erosive potential of the beverages, including Coca-Cola ${ }^{\circledR} .10$

In another study, ${ }^{1}$ the authors analyzed the variations of enamel's microhardness in primary teeth promoted by two drinks, one of which was Coca-Cola ${ }^{\circledR}(\mathrm{pH} 2.35)$, on days 7,15 , 30,45 and 60 . In that evaluation, further analysis was performed on the enamel surface using scanning electron microscopy. That study revealed a decrease in microhardness related to time, as a result of mineral loss caused by the ingestion of acidic beverages. The Coca-Cola ${ }^{\circledR}$ produced statically significant gradual changes associated with variations observed in the surface microhardness at all times, except on day 15 and day 30, when the results were similar. The electronic microscope scanning revealed a progressive destruction of the enamel structure over time. On day 7, a pronounced demineralization was observed over the entire surface, particularly on the enamel prism cross-striations. On the remaining days, there was a gradual loss up to day 30.1 Those results are similar to the ones obtained in this study. However, one must notice that the analyzing methods and the examined teeth were different.

In another in vitro study, ${ }^{26}$ the authors evaluated the erosive potential of different soft drinks in Taiwan, using a novel multiple-erosive method. The results revealed that the $\mathrm{pH}$ values of the soft drinks were below the critical $\mathrm{pH}$ value (5.5) for enamel demineralization and that exposure to all the soft drinks resulted in the loss of human enamel surface (7.28 and $34.07 \mathrm{~mm}$ for a 180-minute exposure).

The present study cannot be fully extrapolated to dental tissues under in vivo conditions since it is not possible to replicate the individual factors influencing the environment of the oral cavity, such as dental anatomy, the composition of dental hard tissues, salivary conditions and real buffer capacity, frequency and duration of consumption of drinks, and other diet habits that can promote dental erosion.

\section{Conclusions}

Based on our results, we conclude that the consumption of Coca-Cola ${ }^{\circledR}$, Fanta ${ }^{\circledR}$ Orange and Lipton ${ }^{\circledR}$ Ice Tea Lemon, over time, caused loss of tooth structure incrementally and that the differences in the soft drinks' erosive potential for the 30-day exposure time were not statistically significant.

\section{Ethical disclosures}

Protection of human and animal subjects. The authors declare that no experiments were performed on humans or animals for this study.

Confidentiality of data. The authors declare that no patient data appear in this article.

Right to privacy and informed consent. The authors declare that no patient data appear in this article.

\section{Conflict of interest}

The authors have no conflicts of interest to declare.

\section{R E F E R E N C E S}

1. Torres CP, Chinelatti MA, Gomes-Silva JM, Rizóli FA, Oliveira MAHdM, Palma-Dibb RG, et al. Surface and subsurface erosion of primary Enamel by acid beverages over time. Braz Dent J. 2010;21:337-45.

2. White I, McIntyre J, Logan R. Studies on dental erosion: An in vitro model of root surface erosion. Aust Dent J. 2001;46:203-7.

3. Jensdottir T, Holbrook P, Nauntofte B, Buchwald C, Bardow A. Immediate Erosive Potential of Cola Drinks and Orange Juices. J Dent Res. 2006;85:226-30.

4. Johansson $A-K$, Lingström P, Imfeld T, Birkhed D. Influence of drinking method on tooth-surface $\mathrm{pH}$ in relation to dental erosion. Eur J Oral Sci. 2004;112:484-9.

5. Honório HM, Rios D, Júnior ESP, Oliveira DSB, Fior FA, Buzalaf MAR. Effect of acidic challenge preceded by food consumption on enamel erosion. Eur J Dent. 2010;4:412-7.

6. Edwards M, Creanor S, Foye R, Gilmour W. Buffering capacities of soft drinks: the potential influence on dental erosion. J Oral Rehabil. 1999;26:923-7.

7. Chu Ch, Pang KKL, Lo ECM. Dietary behavior and knowledge of dental erosion among Chinese adults. BMC Oral Health. 2010;10:13.

8. Davis RE, Marshall TA, Qian F, Warren JJ, Wefel JS. In vitro protection against dental erosion afforded by commercially available, calcium-fortified 100 percent juices. J Am Dent Assoc. 2007;138:1593-8.

9. Hemingway CA, Parker DM, Addy M, Barbour ME. Erosion of enamel by non-carbonated soft drinks with and without toothbrushing abrasion. Br Dent J. 2006;201:447-50.

10. Ehlen L, Marshall T, Qian F, Wefel J, Warren J. Acidic beverages increase the risk of in vitro tooth erosion. Nutr Res. 2008;28:299-303.

11. Sales-Peres S, Magalhães A, Machado M, Buzalaf M. Evaluation of the erosive potential of soft drinks. Eur J Dent. 2007;1:10-3.

12. Wongkhantee S, Patanapiradej V, Maneenut C, Tantbirojn D. Effect of acidic food and drinks on surface hardness of enamel, dentine, and tooth-coloured filling materials. J Dent. 2006;34:214-20.

13. Hannig C, Berndt D, Hoth-Hannig W, Hannig M. The effect of acidic beverages on the ultrastructure of the acquired pellicle - An in situ study. Arch Oral Biol. 2009;54:518-26.

14. Tahmassebi J, Duggal M, Malikkotru G, Curzon M. Soft drinks and dental health: A review of the current literature. J Dent. 2006;34:2-11. 
15. Willershausen B, Schulz-Dobrick B. In vitro study on dental erosion provoked by various beverages using electron probe microanalysis. Eur J Med Res. 2004;9:432-8.

16. Lussi A, Jaeggi T. Erosion-diagnosis and risk factors. Clin Oral Investig. 2008;12(S1):5-13.

17. Rios D, Honorio H, Magalhaes AC, Wiegand A, Machado MAAM, Buzalaf MAR. Light cola drink is less erosive than the regular one: An in situ/ex vivo study. J Dent. 2009;37:163-6.

18. Vaneygen I, Vannet B, Wehrbein H. Influence of a soft drink with low $\mathrm{pH}$ on enamel surfaces: An in vitro study. Am J Orthod Dentofacial Orthop. 2005;128:372-7.

19. Attin T, Weiss K, Becker K, Buchalla W, Wiegand A. Impact of modified acidic soft drinks on enamel erosion. Oral Dis. 2005;11:7-12.

20. von Fraunhofer J, Rogers M. Dissolution of dental enamel in soft drinks. Gen Dent. 2004;52:308-12.

21. Fujii M, Kitasako Y, Sadr A, Tagami J. Roughness and $\mathrm{pH}$ changes of enamel surface induced by soft drinks in vitro-applications of stylus profilometry, focus variation 3D scanning microscopy and micro pH sensor. Dent Mater J. 2011;30:404-10.

22. West N, Hughes J, Addy M. The effect of $\mathrm{pH}$ on the erosion of dentine and enamel by dietary acids in vitro. J Oral Rehabi. 2001;28:860-4.
23. Rios D, Honório HM, Magalhães AC, Silva SMB, Delbem ACB, Andrade MA, et al. Scanning electron microscopic study of the in situ effect of salivary stimulation on erosion and abrasion in human and bovine enamel. Braz Oral Res. 2008;22:132-8.

24. Karlinsey R, Mackey A, Walker E, Frederick K, Fowler C. In vitro evaluation of eroded enamel treated with fluoride and a prospective tricalcium phosphate agent. J Dent Oral Hyg. 2009;1:52-58.

25. Borjian A, Ferrari CCF, Anouf A, Touyz LZG. Pop-Cola Acids and Tooth Erosion: An In Vitro, In Vivo, Electron-Microscopic, and Clinical Report. Int J Dent. 2010;2010:1-12.

26. Wang YL, Chang CC, Chi CW, Chang HH, Chiang YC, Chuang YC, Chang HH, Huang GF, Liao YS, Lin CP. Erosive potential of soft drinks on human enamel: An in vitro study. J Formos Med Assoc. 2014;113:850-6.

27. Brito JS, Santos Neto A, Silva L, Menezes R, Araújo N, Carneiro V, et al. Analysis of Dental Enamel Surface Submitted to Fruit Juice Plus Soymilk by Micro X-Ray Fluorescence: In Vitro Study. ScientificWorldJournal. 2016;2016:8123769.

28. Tedesco TK, Gomes NG, Soares FZ, Rocha RO. Erosive effects of beverages in the presence or absence of caries simulation by acidogenic challenge on human primary enamel: an in vitro study. Eur Arch Paediatr Dent. 2012;13:36-40. 